ppi $201502 Z U 4645$

Esta publicación cientifica en formato digital es continuidad de la revista impresa ISSN-Versión Impresa 0798-1406 / ISSN-Versión on line 2542-3185Depósito legal pp

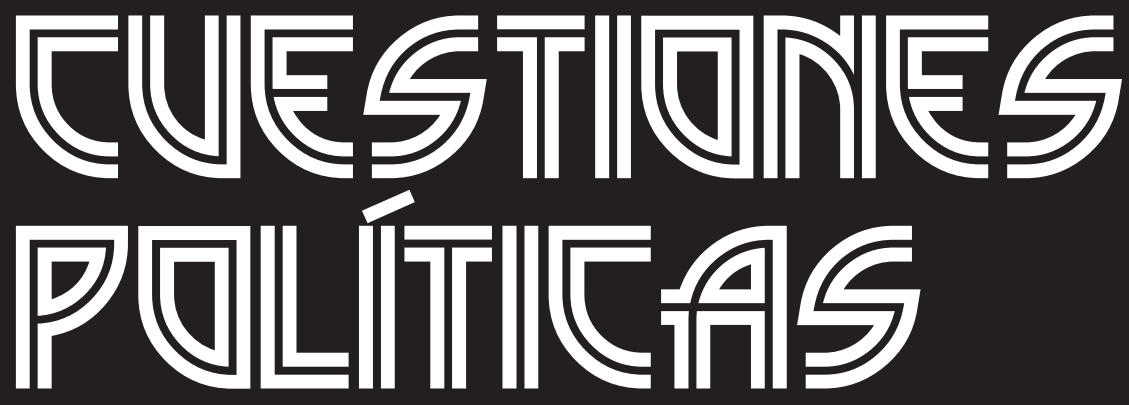

Instituto de Estudios Políticos y Derecho Público "Dr. Humberto J. La Roche' de la Facultad de Ciencias Jurídicas y Políticas de la Universidad del Zulia Maracaibo, Venezuela
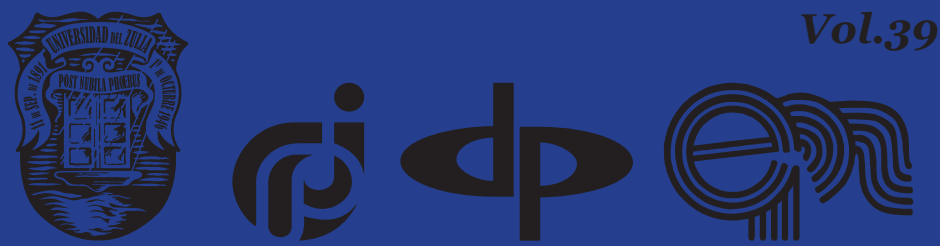


\title{
Competition Status of a Unitary Enterprise: Some Problems
}

\author{
DOI: https://doi.org/10.46398/cuestpol.3968.50
}

\author{
Marina.V. Telyukina * \\ K.B. Shukurova ${ }^{* *}$
}

\begin{abstract}
Problems arising from the insolvency (bankruptcy) procedures of a unitary undertaking are currently very relevant, since, in the context of competition relations, the redistribution of ownership may also take place outside the framework of privatization legislation. This article is dedicated to the analysis of both theoretical and practical problems of the competitiveness of a unitary company. The authors of the paper point out that the lack of a special term for the designation of unitary enterprises on the right to economic management is one of the systemic shortcomings of Russian doctrine of civil law. The study methodology includes a group of general scientific methods (analysis, synthesis, deduction, induction), as well as a group of special methods: analysis of the content of scientific literature and analysis of the regulatory framework. It is concluded that Russian law should create a legal model that excludes the operation of nonproprietary entities alongside legal conditions that prevent abuse of their competitive status, both by the arbitration administrator and by the public legal entity that owns the debtor unitary enterprise.
\end{abstract}

Keywords: unitary enterprise; public law: bankruptcy proceedings; privatization; competitive situation of the unitary enterprise.

* Russian Presidential Academy of National Economy and Public Administration, Moscow, Russia. ORCID ID: https://orcid.org/oooo-0o02-7722-7954. Email: marwict@mail.ru

** State Committee for Investment and State Property Management of the Republic of Tajikistan, Dushanbe, Republic of Tajikistan. ORCID ID: https://orcid.org/oooo-0002-9678-4078. Email: karminashukurova@gmail.com 


\section{Competition Status of a Unitary Enterprise: Some Problems \\ Competitividad de la empresa unitaria: algunos problemas}

\section{Resumen}

Los problemas derivados de los procedimientos de insolvencia (quiebra) de una empresa unitaria son actualmente muy relevantes, ya que, en el marco de las relaciones de competencia, la redistribución de la propiedad también puede tener lugar fuera del marco de la legislación de privatización. Este artículo está dedicado al análisis de problemas tanto teóricos como prácticos de la competitividad de una empresa unitaria. Los autores del artículo señalan que la falta de un término especial para la designación de las empresas unitarias sobre el derecho de gestión económica es una de las deficiencias sistémicas de la doctrina rusa del derecho civil. La metodología del estudio incluye un grupo de métodos científicos generales (análisis, síntesis, deducción, inducción), así como un grupo de métodos especiales: análisis del contenido de la literatura científica y análisis del marco normativo. Se concluye que la legislación rusa debe crear un modelo jurídico que excluya el funcionamiento de las entidades no propietarias junto a las condiciones legales que impidan el abuso de su condición competitiva, tanto por parte del administrador del arbitraje como de la entidad jurídica pública propietaria de la empresa unitaria deudora.

Palabras clave: empresa unitaria; derecho público: procedimiento de quiebra; privatización; situación de competencia de la empresa unitaria.

\section{Introduction}

The legal status is usually understood as the subject's position in the certain relations system determined by the presence of certain rights and obligations (Alekseev, 1981; Arkhipov, 2004; Mikryukov, 2015). Simultaneously, the competitive status is subject's position in the competitive relations system. By competitive relations we understand the relations arising between the debtor, its creditors and third parties in connection with the non-fulfillment of rights and obligations by the debtor; the term "competition law" was used in the pre-revolutionary doctrine (Genkin, 1913; Golmsten, 1888; Karnushin, 2016; Popondopulo, 2001; Telyukina, 2002; Tkachev, 2006) as well as it is widely used now.

Active and passive competitive statuses can be distinguished, meaning the creditor's legal status as active and the debtor's legal status as passive. This article is focused on the features of relations associated with the implementation of bankruptcy case proceedings against a unitary enterprise, in other words, on the passive competitive status of this entity. This design 
- "passive competitive status" - has been developed by the authors of this article and is proposed for use in scientific circulation in order to optimize the doctrine.

\section{Materials and Methods}

Both in theory and in practice, there are many problems, including those which are not resolved at the legislative level (Erokhova, 2015; Sukhanov, 2014), that are solved by different scientists and courts in various ways. Let us dwell on some of them.

It seems logically to start an analysis of the problems in the passive competitive status of a unitary enterprise with a system-forming problem defined by the answer for two questions:

- firstly, is it advisable to allow the inclusion of a unitary enterprise in the subjects of competition law?

- secondly, is it generally advisable to retain the legal form of a unitary enterprise among the subjects of civil law?

\section{Results}

The design of a unitary enterprise is not an immanent in market economy because the legal form of the enterprise, as well as institutions are not implied ownership of the property by this subject. Thus, Russian law (unlike most legal systems) allows, although in a limited version, participation in legal relations of entities that are not owners of the property on which they operate. Many scientists criticize this approach (Andreev, 2005; Braginsky, 1960; Gadzhiev, 1996; Golubtsov, 2010). Through the activities of unitary enterprises, public law object is involved in entrepreneurial relations. The related problems are beyond the scope of this article, so we just note the doctrinal interest in them (Istomin, 2003; Kulagin, 1987; Mochalov, 2016; Sadrieva, 2018; Yakovlev and Talapina, 2012).

In this case, a unitary enterprise may function on the basis of economic management or operational management. The latter has a special name - "state-owned enterprise". The absence of a special term for designating unitary enterprises under the economic management right, in our opinion, is one of the systemic shortcomings of the Russian civil law doctrine.

The institution operates on the operational management right, which differs essentially from the operational management right of a state-owned enterprise. In this context, there is one more defect of the Russian civilist doctrine, which can be generically designated as naming various relations by the same term. Thus, the operational management right of a state-owned 
enterprise, by no means, is not the same as the operational management right of an institution. Nevertheless, the term "operational management" is used to designate both structures that should be differentiated.

By virtue of the norms, clause 1 of Article 65 in the Civil Code of the Russian Federation (Federal Law of the Russian Federation, 2002a), the passive competitive status is used for only unitary enterprises based on the economic management right. Using the term "competitiveness", known in modern doctrine (Galkin, 2016; Suvorov, 2019; Shishmareva, 2016), it can be said that state-owned enterprises and institutions are not competitive.

The Law "On Insolvency (Bankruptcy)" does not contain a special chapter (or other location of legal norms) for regulation of the particularities in the case proceedings on bankruptcy of a unitary enterprise. At the same time, the Law contains the chapter "Bankruptcy of Strategic Enterprises", as well as the chapters for regulation the general insolvency (bankruptcy) procedure contain rules (mainly, which are relatively recent legislative changes) that define the particular status of a unitary enterprise.

From the foregoing it follows that one of the problems in Russian competition law can be defined the correlation problem between the norms of a special chapter for regulation the bankruptcy of strategic enterprises and the norms, contained in the general chapters, for regulation the position of a unitary enterprise in the tender procedures. The fact is that a unitary enterprise may possess the characteristics of a strategic enterprise, however, other entities (not just unitary enterprises) may be identified as strategic. A detailed discussion of this issue is beyond the scope of this article. Features of the competitive status of strategic organizations are investigated in the doctrine (Chirkov, 2014).

The next problem of the competitive status of a unitary enterprise is determined by the very possibility of applying the procedures, provided for by the Law on Bankruptcy, to unitary enterprises under the economic management right. In the process of bankruptcy proceedings of any legal entity, such procedures as supervision, financial recovery, external management, bankruptcy proceedings may be introduced. Without dwelling on the essence of these procedures and noting the interest on the part of scientists (Order of the Government of the Russian Federation, 2009; The Decision of the Arbitration Court of the North-Western District, 2019; Resolution of the Arbitration Court of the Far Eastern District, 2018), we turn directly to the problem, which is that the Law on Bankruptcy allows the sale of debtor's assets, including a unitary enterprise, as part of external management and bankruptcy proceedings. As a result, the owner of the assets of a unitary enterprise (which can be the Russian Federation itself, the subject of the Federation and the municipality) may lose these assets, which will be transferred to the property buyer. However, in Russian law, the transfer of property from public law object to private individuals has 
a special name - privatization - and special legal regulation with complex multifaceted privatization legislation (Egorov, 2019; Koraev, 2018; Lipkin and Barsky, 2017; Miftakhutdinov, 2013; Mikryukov, 2015). Doctrinal studies of privatization can be described as complex and multidimensional (Olenin, 2000; Tkachev, 2006; Telyukina, 2018; Telyukina, 2001).

As a result, we can conclude that there is a parallelization of legal norms or, in other words, there is competition for legal regulation of the property transfer from public law education to private individuals, which, in our opinion, is a drawback of the legal technique of Russian legislation (Federal Law of the Russian Federation, 2002b; Federal Law of the Russian Federation, 2001; Decree of the President of the Russian Federation, 1994; Decree of the Government of the Russian Federation, 2009; Resolution of the Arbitration Court of the Far Eastern District). The term "quasiprivatization" is not commonly used; in the opinion of the authors of this article, it must be put into scientific circulation to indicate the relations that develop in connection with the property transfer from public ownership to private in the process of insolvency (bankruptcy) proceedings.

\section{Discussion}

The problem of the implementation of quasi-privatization term is associated with the problem of the retained competence of the property owner in a unitary enterprise. The design of the retained competence was introduced into the Law on Bankruptcy with the aim of protecting the property owner of a unitary enterprise, that is, public law object, from actions, aimed at seizing a business carried out by an arbitration manager in the interests of invaders (raiders), are possible because all the powers of all authority's management of the debtor legal entity after the introduction of external management pass to the arbitration manager.

Accordingly, before to the standards introduction on retained competence into the competition law, the arbitration manager, having the authority of all management bodies, could, for example, decide to sell the debtor's business at an unprofitable price or conclude a fulfilment agreement by a third party of the debtor's obligations at non-profitable conditions for debtor. Generally, have been used various schemes of raider seizures through bankruptcy manifest in practice (Telyukina, 2017), this issue is also studied in the doctrine (European Court of Human Rights, 2014).

The inclusion of the retained competence design led to the arbitration manager becoming obligated to coordinate with the property owner of the unitary enterprise issues related to the disposal of the debtor's assets. In this regard, on the one hand, there are guarantees that the arbitration manager is not able to arbitrarily perform actions aimed at implementing quasi-privatization. 
However, on the other hand, the property owner of a unitary enterprise (represented by certain officials of the state (municipal) body responsible for property managing) may not agree to certain measures, the implementation of which can restore the solvency of the debtor. This problem can be positioned as follows - this is a problem determined by the absence in the current legislation of mechanisms to challenge the property owner' refusal of the unitary enterprise to approve the actions of the arbitration manager aimed at the property disposing of the unitary enterprise as a debtor.

A different order problem, related to the retained competence, is determined by the fact that at the stage of bankruptcy proceedings the governing bodies of the debtor do not retain any powers, that is, the bankruptcy trustee can make any decisions which opens up the abuse possibility.

Another block of problems is related to the fact that in practice public law object often illegally disposes of the unitary enterprise' assets, redistributing them, despite the prohibition in both the Civil Code of the Russian Federation and the Law on Unitary Enterprises, which often leads to a bankruptcy of a unitary enterprise. And although there is no subsidiary liability of public law object for the debts of a unitary enterprise, there is a practice of the European Court of Human Rights in which the Russian Federation is obligated to compensate citizens who have not received wages, losses and non-pecuniary damage as a result of bankruptcy (Voevodkin, 2017; Grishchenko and Martynov, 2018; Ivanov, 2015; Demchenko, 2015; Popondopulo, 2015); we should note doctrinal interest in this issue.

\section{Conclusion}

Summarizing what was said in this article, we note that many competitive features of a unitary enterprise status in Russian law are determined by its anomalous legal nature, especially the lack of ownership of the property that this legal form owns. The strategic objective of science is to create a legal model that excludes the functioning of non-owner entities; the tactical task is to create legal conditions that prevent the abuse of its competitive status by both the arbitration manager and the public legal entity-owner of the property of the debtor-unitary enterprise.

\section{Bibliographic References}

ALEKSEEV, Sergey Sergeevich. 1981. General theory of law: In 2 vols. Legal literature. Moscow, Russia.

ANDREEV, Yuri N. 2005. State participation in civil law relations. Yuridicheskiy tsentr Press. St. Petersburg, Russia. 
ARKHIPOV, Sergey Ivanovich. 2004. Subject of law: theoretical study. Yuridicheskiy tsentr Press. St. Petersburg, Russia.

BRAGINSKY, M.I. 1960. The Soviet state as a subject of civil law. In: V.A. Ryasentsev (Ed.), Soviet Civil Law. Part 1 (p. 34). VYUZI Publication. Moscow, Russia.

CHIRKOV, Oleg Gennadievich. 2014. "Features of bankruptcy procedures for strategic enterprises and organizations: current issues and their solutions" In: Judge. No. 12, pp. 50 - 56.

DECREE OF THE GOVERNMENT OF THE RUSSIAN FEDERATION NO. 995. (DECEMBER 10, 2009). 2009. "On the procedure and conditions for the restructuring of debts of organizations of the military-industrial complex - executors of the state defense order included in the list of strategic organizations for taxes and fees charged penalties and fines before the federal budget and write-offs of these penalties and fines" (as amended on May 31, 2012). Available online. In: http://government.ru/ docs/all/70508/. Consultation date: 08/03/2020.

DECREE OF THE PRESIDENT OF THE RUSSIAN FEDERATION NO. 1535. (JULY 22, 1994).1994. "On the Basic Provisions of the State Program for the Privatization of State and Municipal Enterprises in the Russian Federation after July 1, 1994" (as amended of October 22, 2014). Sobranie Zakonodatel'stva Rossiiskoi Federatsii [SZ RF] [Collection of Legislation of the RF] 25.07.1994, No. 13, Item 1478.

DEMCHENKO, Alena Sergeevna. 2015. "Legal methods of protection against hostile takeovers in the Russian Federation" In: Actual problems of Russian law. Vol. 8, No. 57, pp. 84-90.

EGOROV, A.V. 2019. "Bankruptcy proceedings: commentary on key points” In: Civil Law Bulletin. No. 1, pp. 114-139.

EROKHOVA, M.A. 2015. "Objects taken out of circulation: the approach of the Supreme Court of the Russian Federation: Commentary on the Determination of the Judicial Collegium for Economic Disputes of the RF Armed Forces of February 13, 2015 in the case N 308-ES14-5118” In: Bulletin of the Economic Justice of the Russian Federation. No. 3, pp. 44-47.

EUROPEAN COURT OF HUMAN RIGHTS. (October 9, 2014). 2014. Liseytseva and Maslov Case Nos. 39483/05 40527/10. Strasbourg, France.

FEDERAL LAW OF THE RUSSIAN FEDERATION NO. 127-FZ. 2002a. "On Insolvency (Bankruptcy)" (as amended on December 27, 2018). Sobranie Zakonodatel'stva Rossiiskoi Federatsii [SZ RF] [Collection of Legislation of the RF] 28.10.2002, No. 43, Item 4190. 
Marina.V. Telyukina y K.B. Shukurova
784 Competition Status of a Unitary Enterprise: Some Problems

FEDERAL LAW OF THE RUSSIAN FEDERATION NO. 161-FZ. (NOVEMBER 14, 2002). 2002b. “On State and Municipal Unitary Enterprises"(as amended on November 28, 2018). Sobranie Zakonodatel'stva Rossiiskoi Federatsii [SZ RF] [Collection of Legislation of the RF] 02.12.2002, No. 48, Item 4746.

FEDERAL LAW OF THE RUSSIAN FEDERATION NO. 178-FZ. 2001. "On the Privatization of State and Municipal Property"(as amended on July 3, 2016). Available online. In: http://pravo.gov.ru/proxy/ ips/?docbody=\&nd=102074022. Consultation date: 08/03/2020.

GADZHIEV, Gadis Abdullaevich. 1996. Basic economic rights (comparative study of constitutional and legal institutions of Russia and foreign countries): Dis. Dr.jur. sciences. Institute of Legislation and Comparative Law under the Government of Russian Federation. Moscow, Russia.

GALKIN, Sergey Sergeevich. 2016. “The doctrine of the debtor in the competition law of Russia and the national economic policy" In: Entrepreneurial law. No. 3, pp. 32-38.

GENKIN, Dmitry Mikhailovich. 1913. Tothe upcoming reform of the competition law. Legal Bulletin. Book 1, 28. Moscow, Russia.

GOLMSTEN, A. Kh. 1888. Historical outline of the Russian competitive process. the Printing house of V.S. Balashev. St. Petersburg, Russia.

GOLUBTSOV, Valery Gennadievich. 2010. "The state as a private legal entity: legal nature and features" In: Journal of Russian Law. No. 10, pp. 61-77.

GRISHCHENKO, Leonid Leonidovich; MARTYNOV, Dmitry Vladimirovich. 2018. "Raiding as a modern threat to business interests" In: Business Security. No. 3, pp. 23-29.

ISTOMIN, V.G. 2003. "Some aspects of the participation of public law entities in civil matters. In: Actual problems of civilistic branches of law" In: Interuniversity collection of scientific papers, Issue 3. Statut. Moscow, Russia.

IVANOV, Anton Aleksandrovich. 2015. "The Problem of the Primitivization of Civil Law of Russia” In: The Law. No. 5, pp. 58-64.

KARNUSHIN, V.E. 2016. “Competitive material legal relationship” In: Legal world. Vol. 7, pp. 39-42.

KORAEV, Konstantin Borisovich. 2018. Insolvency: New Institute for Legal Regulation of Financial Recovery and Insolvency (Bankruptcy): Monograph. Prospect. Moscow, Russia. 
KULAGIN, Mikhail Ivanovich. 1987. State-monopoly capitalism and legal entity. Publishing House of the Peoples' Friendship University of Russia. Moscow, Russia.

LIPKIN, I.B; BARSKY, I.V. 2017. "Bankruptcy Rehabilitation Procedures" In: Arbitration Manager. No. 2, pp. 25-30.

MIFTAKHUTDINOV, R.T. 2013. The abolition of the monitoring procedure as one of the main measures to improve domestic bankruptcy law and its consequences de lege ferenda. In: V.A. Golubtsoa, O.A. Kyznertsova (Eds.), 20 years of the Constitution of the Russian Federation: actual problems of legal science and law enforcement in the context of improving Russian legislation: Fourth Perm International Congress of Lawyers, October 18-19, 2013, Perm, Statut. Moscow, Russia.

MIKRYUKOV, Viktor Alekseevich. 2015. "Problems of including information on the civil status of organizations in the Unified State Register of Legal Entities” In: Laws of Russia: experience, analysis, practice. No. 9, pp. 8791.

MOCHALOV, S.Yu. 2016. "Some legal problems of the participation of public law entities in civil matters" In: Actual problems of Russian law. No. 3, pp. 89-99.

OLENIN, A.E. 2000. "Legal basis and features of observation as a bankruptcy procedure" In: Legislation. No. 2, pp. 37.

ORDER OF THE GOVERNMENT OF THE RUSSIAN FEDERATION NO.1226-R. (AUGUST 20, 2009). 2009. "On approval of the list of strategic organizations, as well as federal executive bodies, ensuring the implementation of a unified state policy in the sectors of the economy in which these organizations operate"(as amended on April 11, 2019). Sobranie Zakonodatel'stva Rossiiskoi Federatsii [SZ RF] [Collection of Legislation of the RF] 31.08.2009, No. 35, Item 4288.

POPONDOPULO, Vladimir Fedorovich. 2001. Competition law: Legal regulation of insolvency (bankruptcy): Textbook. Lawyer. Moscow, Russia.

POPONDOPULO, Vladimir Fedorovich. 2015. Criteria and signs of bankruptcy in the light of recent changes in bankruptcy law. In: S.D. Mogilevsky, M.A. Egorova (Eds.) Collection of scientific and practical articles of the II International scientific and practical conference "Actual problems of business and corporate law in Russia and abroad", April 22, 2015. Yustitsinform. Moscow, Russia. 
Marina.V. Telyukina y K.B. Shukurova
$786 \quad$ Competition Status of a Unitary Enterprise: Some Problems

RESOLUTION OF THE ARBITRATION COURT OF THE FAR EASTERN DISTRICT NO. Fo3-5147. (DECEMBER 6, 2018). 2018. Moscow, Russia.

SADRIEVA, R.R. 2018. "Equal beginnings of the speech of the Russian Federation with other participants in civil relations" In: Notary, No. 7, pp. 17-20.

SHISHMAREVA, T.P. 2016. "Insolvency problems of separate property masses" In: Entrepreneurial law, The application "Law and Business". No. 3, pp. 50-54.

SUKHANOV, E.A. 2014. Comparative corporate law. Statute. Moscow, Russia.

SUVOROV, Evgeny Dmitrievich. 2019. Bankruptcy in the practice of the Supreme Court of the Russian Federation and the Supreme Arbitration Court of the Russian Federation: an encyclopedia of legal positions for 2014 - 2018. Statute. Moscow, Russia.

TELYUKINA, Marina Viktorovna. 2001. "Some issues of external management of the debtor's property” In: Legislation and Economics. No. 7, pp. 30-34.

TELYUKINA, Marina Viktorovna. 2002. Competition law: theory and practice of insolvency. Delo. Moscow, Russia.

TELYUKINA, Marina Viktorovna. 2017. "Quasiprivatization and other features of the insolvency (bankruptcy) of a unitary enterprise: Appendix to the monthly legal scientific and practical" In: Journal Economy and Law. No. 5 , pp 3-48.

TELYUKINA, Marina Viktorovna. 2018. "System analysis of the observation procedure and the practical problems of its implementation" In: Economy and Law. No. 5, pp. 3-25.

THE DECISION OF THE ARBITRATION COURT OF THE NORTHWESTERN DISTRICT NO. ФO7-16181. (JANUARY 28, 2019). 2019. Moscow, Russia.

TKACHEV, Valentin Nikolaevich. 2006. Competition law: legal regulation of insolvency (bankruptcy) in Russia: Textbook. Knizhnyy mir. Moscow, Russia.

VOEVODKIN, Aleksey Vadimovich. 2017. "Legal structure of raiding" In: Russian investigator. No. 9, pp. 23-26.

YAKOVLEV, Veniamin Fedorovich; TALAPINA, Elvira Vladimirovna. 2012. "The role of public and private law in the regulation of the economy" In: Journal of Russian Law. No. 2, pp. 5-16. 

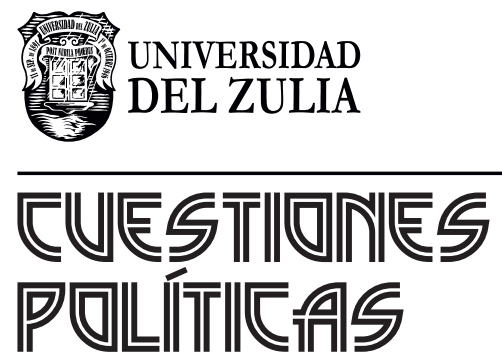

Vol.39 No 68

Esta revista fue editada en formato digital y publicada en enero de 2021, por el Fondo Editorial Serbiluz, Universidad del Zulia. Maracaibo-Venezuela 